\title{
ПРОБЛЕМИ ОРГАНІЗАЦІЇ ТА НАДАННЯ ВИСОКОСПЕЦІАЛІЗОВАНОЇ МЕДИЧНОЇ ДОПОМОГИ ЗА УМОВ ПРОВЕДЕННЯ АНТИТЕРОРИСТИЧНОЇ ОПЕРАЦІЇ - ОПЕРАЦІЇ ОБ’ ЄДНАНИХ СИЛ НА ТЕРИТОРІЇ, ПІДКОНТРОЛЬНІЙ УРЯДУ УКРАЇНИ (ЛУГАНСЬКА ОБЛАСТЬ)
}

\author{
Н. М. Стешенко ${ }^{1}$, О. Н. Литвинова ${ }^{2}$ \\ ${ }^{1}$ Комунальне некомериійне підприємство Луганської обласної ради \\ "Луганська обласна клінічна лікарня" \\ ${ }^{2}$ Тернопільський національний медичний університет \\ імені І. Я. Горбачевського МОЗ Украӥни
}

\begin{abstract}
У статті висвітлено проблемні питання організації та надання високоспеціалізованої медичної допомоги на території Луганської області, підконтрольній уряду України, за умов проведення антитерористичної операції - Операції об’єднаних сил. Акцентовано увагу на недостатності, а подекуди і відсутності забезпечення доступу населення до високоспеціалізованої медичної допомоги на даній території.
\end{abstract}

\section{PROBLEMS OF ORGANIZATION AND PROVISION OF HIGHLY SPECIALIZED MEDICAL CARE IN THE CONDITIONS OF ANTI-TERRORIST OPERATION - JOINT FORCES OPERATIN ON THE TERRITORY UNDER CONTROL OF THE GOVERNMENT OF UKRAINE (LUHANSK REGION)}

\author{
N. M. Steshenko ${ }^{1}$, O.N. Lytvynova ${ }^{2}$ \\ ${ }^{1}$ Municipal non-profit enterprise of Luhansk Regional Council \\ "Luhansk Regional Clinical Hospital" \\ ${ }^{2}$ I. Horbachevsky Ternopil National Medical University
}

\begin{abstract}
The article highlights the problematic issues of organization and provision of highly specialized medical care on the territories of Luhansk region, controlled by the Government of Ukraine in the conditions of anti-terrorist operation - joint forces operation. Emphasis is placed on the insufficiency, in some places and lack of access of the population to specialized medical care in these areas.
\end{abstract}

Вступ. У зв'язку з тимчасовою окупацією частини Луганської області та триваючими бойовими діями соціальна інфраструктура області зазнала значних втрат.

Найбільші втрати в галузі охорони здоров'я із 2014 р. зазнали заклади високоспеціалізованої медичної допомоги (третинний рівень медичної допомоги). Система надання високоспеціалізованої медичної допомоги населенню в області практично перестала існувати - на непідконтрольній українській владі території області залишилося 11 з 14 міст обласного значення, у тому числі обласний центр м. Луганськ, де були розташовані майже всі обласні

(c) Н. М. Стешенко, О. Н. Литвинова, 2021 лікувальні заклади, оснащені сучасним медичним обладнанням, які надавали населенню високоспеціалізовану медичну допомогу третинного рівня.

Основна частина. Населення Луганської області станом на 01.01.2019 р. склало 2151,8 тис. осіб (5,1% від населення України) [1]. На території області, підконтрольній українській владі, чисельність наявного населення на 01.01.2019 р. склала 723,4 тис. осіб, у тому числі 684,1 тис. осіб постійного населення. Демографічна ситуація в Луганській області залишається складною і погіршується. Протягом 20142018 рр. чисельність наявного населення області зменшилася з 2220,2 до 2151,8 тис. осіб, але попри це регіон входить до 10 найбільших за чисельністю населення областей України (рис. 1).

14 ISSN 2411-1597. МЕДСЕСТРИНСТВО. 2021. № 2 
Із 2014 р. місто обласного значення С $\in$ вєродонецьк виконує функції обласного центру, в ньому розміщено Луганську обласну державну адміністрацію - обласну військово-цивільну адміністрацію та інші установи.

У зв'язку з військовими діями та проведенням антитерористичної операції (АТО), в Луганській області на підставі Постанови Кабінету Міністрів України від 07.11.2014 р. № 595 «Деякі питання фінансування бюджетних установ, здійснення соціальних виплат населенню та надання фінансової підтримки окремим підприємствам і організаціям
Донецької та Луганської областей, а також інших платежів з рахунків, відкритих в органах Казначейства» ( https://zakon.rada.gov.ua) і наказу Департаменту охорони здоров'я від 03.11.2014 р. № 1 «Про організацію роботи Луганської обласної клінічної лікарні на території, підконтрольній уряду України» провели перереєстрацію лікарні у м. Сєвєродонецьку в листопаді 2014 р. і на підконтрольну територію України частково перемістили обласні медичні установи.

Дані про заклади охорони здоров'я та медичні кадри Луганської області наведено в таблиці 1.

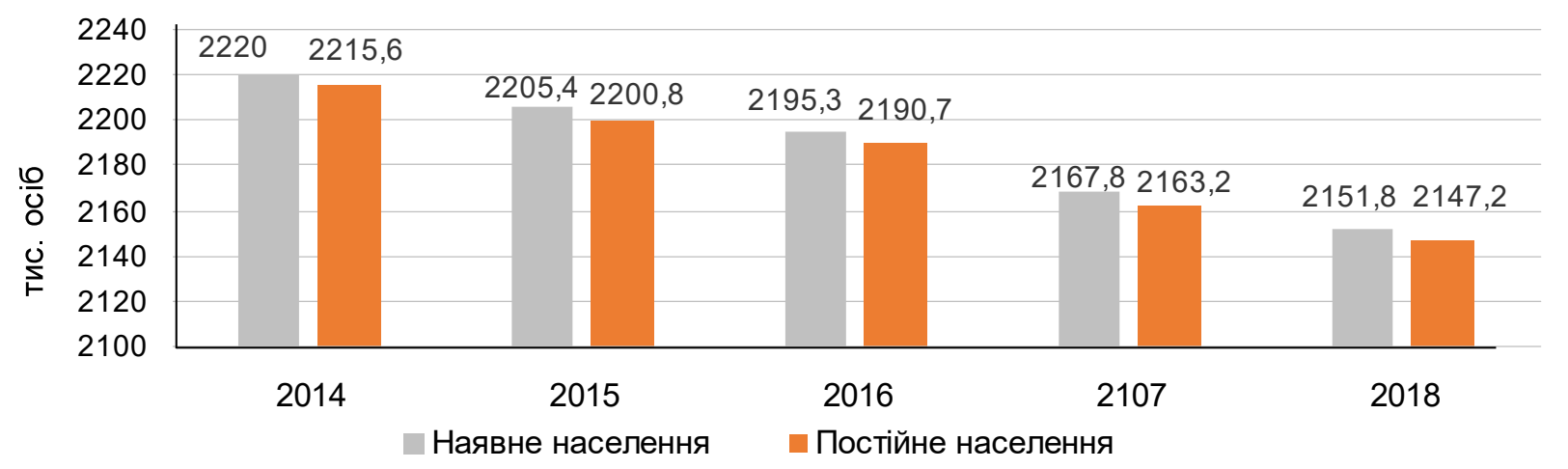

PUс. 1. Чисельність населення Луганської області.

Табличя 1. Заклади охорони здоров'я та медичні кадри Луганської області

\begin{tabular}{|c|c|c|c|c|c|}
\hline Рік & $\begin{array}{c}\text { Кількість } \\
\text { лікарняних } \\
\text { закладів, од. }\end{array}$ & $\begin{array}{c}\text { Кількість } \\
\text { лікарняних ліжок } \\
\text { всього, тис. }\end{array}$ & $\begin{array}{c}\text { Кількість } \\
\text { амбулаторно- } \\
\text { поліклінічних } \\
\text { закладів, од. }\end{array}$ & $\begin{array}{c}\text { Кількість лікарів усіх } \\
\text { спеціальностей } \\
\text { всього, тис. }\end{array}$ & $\begin{array}{c}\text { Кількість середнього } \\
\text { медичного персоналу } \\
\text { всього, тис. }\end{array}$ \\
\hline 2013 & 126 & 21,2 & 558 & 9,4 & 20,6 \\
\hline $2014^{1}$ & 25 & 4,9 & 198 & 2,0 & 5,3 \\
\hline $2015^{1}$ & 30 & 7,2 & 209 & 2,1 & 5,3 \\
\hline $2016^{1}$ & 27 & 6,5 & 204 & 2,1 & 5,4 \\
\hline $2017^{1}$ & 27 & 6,5 & 207 & 2,2 & 5,5 \\
\hline $2018^{1}$ & 27 & 6,1 & 209 & 2,0 & 5,2 \\
\hline
\end{tabular}

Примітка. ${ }^{1}$ - без урахування частини тимчасово окупованої території у Луганській області.

3 метою продовження надання високоспеціалізованої медичної допомоги третинного рівня населенню області на підконтрольній Україні території почався процес реорганізації. Були поставлені завдання: перереєстрація за новими адресами, відновлення втрачених документів, печаток, ліцензій на лікарську практику та по роботі з наркотичними засобами.

Керівний склад формувався з лікарів і медсестер, які прибули з різних лікувальних закладів окупованої частини Луганської області на територію, на той час підконтрольну уряду України.
Зокрема, планувалось розмістити та відновити діяльність таких медичних закладів із надання медичної допомоги третинного рівня:

- Луганської обласної дитячої клінічної лікарні;

- Луганської обласної клінічної лікарні та перинатального центру;

- Луганського обласного клінічного онкологічного диспансеру;

- Луганського обласного кардіологічного диспанcepy;

- Луганського обласного наркологічного диспанcepy; 
- централізованої лабораторії;

- Луганського обласного бюро судово-медичної експертизи;

- клініко-діагностичної лабораторії;

- Луганського обласного центру СНІДу та централізованої лабораторії діагностики ВІЛ та вірусних гепатитів.

3 жовтня 2014 р. при Департаменті охорони здоров'я лОДА тривала напружена робота із формування кадрів для відновлення роботи переміщених закладів. Перед керівниками обласних лікувальнопрофілактичних закладів (ЛПЗ) постали проблеми:

1. Оренда приміщень, де будуть розміщені відділення лікарень.

2. Пошук середнього та молодшого медичного персоналу, а почасти і лікарських кадрів.

3. Налагодження ефективної роботи підрозділів на базі міських ЛПЗ шляхом організації чіткої схеми забезпечення таких допоміжних підрозділів, як лабораторія, рентген, харчування та ін.

4. Облаштування та оснащення відділень лікувально-профілактичних закладів медичним обладнанням, меблями та витратними матеріалами.

Незважаючи на значні обсяги адміністративних організаційних заходів, медичне забезпечення населення Луганської області (зони проведення АТО) у розрізі надання високоспеціалізованої медичної допомоги залишається незадовільним.

3 невирішених проблемних питань залишились розміщення обласних закладів та оренда приміщень або площ у лікувальних закладах міст.

Серед переміщених лікувальних закладів Луганська обласна клінічна лікарня як і раніше залишається провідним медичним закладом області, на який покладено відповідальність за отримання, зберігання та видачу лікарських препаратів і медичних виробів, що забезпечують хворих мешканців області відповідно до державних програм [2].

Станом на 01.01.2021 р. обласні медичні заклади, що перемістились на територію, підконтрольну українській владі, знаходяться в орендованих приміщеннях міських лікарень м. Сєвєродонецьк, Лисичанськ, Рубіжне і Кремінна. Зрозуміло, що умови в переміщених установах далекі від реальних вимог до облаштування закладів третинного рівня медичної допомоги. Лікарні продовжують працювати в складних умовах нестабільності в регіоні.

Керівництво Луганської обласної клінічної лікарні певною мірою вирішило питання оренди примі- щень для розміщення та організації роботи складів (отримання та видача ліків, інсуліну та медичних виробів, які надходять відповідно до державних програм), для забезпечення жителів та тимчасово переміщених осіб Луганської області. Також адміністрація обласної лікарні стала координатором розподілу гуманітарної допомоги від благодійних організацій, Червоного Хреста та ін. серед медичних закладів Луганщини. І одним із важливих заходів $\epsilon$ налагодження діяльності відділення гемодіалізу, яке розташоване в орендованому приміщенні на першому поверсі двоповерхової будівлі (колишній дитсадок) і має все необхідне якісне обладнання, для проведення життєво необхідної процедури більш ніж 40 хворим на хронічну ниркову недостатність Луганської області в 4 зміни на добу, 6 днів на тиждень на 8 діалізних апаратах «штучна нирка».

Відновлено надання високоспеціалізованої хірургічної та ортопедо-травматологічної допомоги, а також роботу обласної консультативної допомоги населенню області та забезпечення хворих безкоштовними ліками та медичними виробами згідно 3 державними програмами (діабет, трансплантологія, онкогематологія, серцево-судинні захворювання та ін.).

Відділення Луганської обласної клінічної лікарні розміщені у трьох різних населених пунктах, а саме:

- м. Сєвєродонецьк - обласна консультативна поліклініка, відділення гемодіалізу, відділення комп'ютерної томографії, відділення лікувальної фізкультури та спортивної медицини, а також санавіація та адміністрація лікарні;

- м. Лисичанськ - відділення судинної хірургії (10 ліжок), ортопедо-травматологічне (30 ліжок), анестезіологічне та урологічне відділення (10 ліжок), клінічна лабораторія;

- м. Рубіжне - хірургічне відділення (з 30 колопроктологічними та щелепно-лицевими ліжками).

Також владою України та керівництвом Луганської області налагоджено зв'язки з міжнародними донорами із ремонту будівель та відновлення роботи лікарень. Зокрема, завдяки виділеним Японією спонсорським коштам, у травні 2015 р. для потреб обласної клінічної лікарні у Сєвєродонецьку розроблено проектно-кошторисну документацію для проведення капітальних ремонтів. Однак на той час тривали запеклі бої, тому вирішили віддати два найбільші приміщення мобільному 59-му військовому шпиталю. Укладено договір оренди щодо корпусів 
3641,6 м² та 2171,1 м² між штабом Об'єднаних сил і керівництвом Луганської обласної військово-цивільної адміністрації та тривали консультації щодо спільного використання будівлі обласної клінічної лікарні та 59-го військового шпиталю з метою максимально ефективного обслуговування цивільних і військових. Однак перевага залишилась за військовими, а всі ці 5 років для Луганщини гостро стоїть питання відновлення медицини третього рівня, бо сьогодні жителі області отримують таку допомогу не в повному обсязі.

Через обмеження лікувально-діагностичних можливостей та неспроможності на належному рівні, в повному обсязі надавати високоспеціалізовані медичні послуги, Луганська обласна клінічна лікарня продовжує працювати із перенавантаженням.

\section{СПИСОК ЛІТЕРАТУРИ}

1. Всеукраїнський перепис населення України [Електронний ресурс]. - Режим доступу : http://www.ukrstat.gov.ua/ Perepis. - Назва з екрана.

2. URL : https://moz.gov.ua/article/health/jakimi-likami-tamedichnimi-virobami-zabezpechujutsja-pacienti-zavdjakiderzhavnim-zakupivljam.
В особливо складних випадках породіль з новонародженими приймають перинатальні центри Харкова, Дніпропетровська, Запоріжжя та Києва [3].

Висновки. Незважаючи на певні зусилля місцевих адміністрацій, на Луганщині відсутня цілісна трьохрівнева система надання третинного рівня медичної допомоги. Система надання високоспеціалізованої медичної допомоги населенню в області практично мінімальна через гострий дефіцит медичних кадрів, відсутність житлового фонду і для медперсоналу, і для тимчасово переміщених осіб, низький рівень заробітної плати медичним працівникам з поєднанням пресінгу військової ескалації.

3 іншого боку, Стратегія розвитку Луганської області до 2027 р. обіцяє відновити та розбудувати систему надання спеціалізованої медичної допомоги.

3. Надання першої допомоги без страху подальшого покарання [Електронний ресурс]. - Режим доступу : https://www.medsprava.com.ua/news/497-usyevyerodonetsku-nezabarom-vidkrijut-usi-viddilennjaluganskoyi-oblasnoyi-likarni.

Отримано 01.04.21 